\title{
The Aspects of Sustainable Development in Mineral Resources Management
}

\author{
Michat ZUBEK ${ }^{1)}$
}

\begin{abstract}
1) $\mathrm{PhD}$ in Economic Sciences in the field of management sciences. Warsaw School of Economics (SGH), Collegium of Business Administration, Institute of Human Capital. His main scientific interests include the use of controlling tools in the enterprises' activity, especially methods of managing, personal controlling, personnel management, human resource analytics and financing of business entities. He has practical experience in public and equal private sector as a manager; email: mzubek@sgh.waw.pl; ORCID number: 0000-0002-9280-8503
\end{abstract}

http://doi.org/10.29227/IM-2021-01-15

Submission date: 29-01-2021 | Review date: 27-05-2021

Abstract
Mineral resources provide a high standard of living for modern societies: satisfying electricity demand as well as demand for construc-
tion materials and they sustain the basis for industry and technological development. Now, modern societies are facing the challenge of
reversing the trend of the depletion of non-renewable mineral resources and sustainable development is intended to ensure the survival
of human civilization in the face of dwindling non-renewable raw materials (especially energy resources) and also increasing anthro-
popression and related environmental pollution. The amount of non-renewable mineral resources of the Earth's crust is limited. Under
specific conditions there is a possibility of their regeneration however over a period of several if not more than a dozen generations. The
article raises questions how societies can prevent mineral resources crises in future and whether this task is feasible.
The article identifies the main aspects of the sustainable development in mining sector in Poland as well as environmental challenges
related to the new CSR mechanism which are: the creation and implementation of sustainable and responsible business model which
thanks to reformed financial and economic system, will make creating a better future easier, more natural and more cost-effective.
The crucial aspects of sustainable development as economic and social conditions, environmental challenges, safety of agglomeration
located in the area of exploitation of resources or in its neighborhood were also presented in the article. The author highlighted the
legal conditions for the management of deposits and extracted mineral resources as well as work safety and research and development
activities in the sector.

Keywords: mineral resources, sustainable development, research and development expenses

\section{Introduction}

Today, the concept of sustainable development is widely used in many areas of human life. It appeared for the first time in the second half of 20th century as a reaction to negative environmental consequences of dynamic economic growth which often occurs with uncontrolled and too intensive use of natural resources. Under the auspices of the United Nations, at the end of the 1960s they were taken the actions to prevent a world-unfavorable phenomenon which were included in the World Commission on Environment and Development Report from 1987: Our Common Future. In Poland, the principle of sustainable development is enshrined in the constitution. Its definition is contained in The Act of 20 May 2020 Environmental Protection Law (Journal of Laws - Dz. U. 2020, item 1219, consolidation).

The aim of the paper is to prove that the principles of sustainable development in extractive industry are not respected at all or only partially. The basic research questions are following:

1. Whether companies apply the principle of sustainable development in a comprehensive manner?

2. Whether there are conditions for the application of the principles of sustainable development. Moreover, there is a need to ask a question?

3. If the entities analyze and report the results of these activities, recognizing information as the main feature of prosocial behaviors in sustainable development?.
The responses that need to be found to these questions allow the verification of the main hypothesis which assumes that not all companies apply the principles of sustainable development which are derived from its definition. The part of companies applies the principles, but not to the full extent.

In order to deepen the verification, the author formulates the sub-hypotheses:

1. There is significant untapped potential for companies' building awareness in a sustainable development sphere.

2. Law and legislation conditions are insufficient to build companies' sustainable development awareness.

In the article were used qualitative comparative methods [Nadolna, 2009, p.140] and Individual In-depth Interview method (IDI) which were conducted as part of the statutory research conducted in 2019 and 2020 by The Collegium of Business Administration Warsaw School of Economics in Warsaw in which the author participated as a member of the research team. Within the quantitative methods the author employs statistical methods. Furthermore, the critical content analysis with existing data analysis was also conducted.

A sustainable organization is based on Triple Bottom Line (TBL) theory which combines social, environmental and economic goals. These objectives are realized through collaboration between the organization and customers, suppliers, local communities and other stakeholders. The short-term statutory aims as well as additional ones including: the will to learn, 
Tab. 1. Documented balance and industrial mineral resources in Poland as od 31.12.2019 in million tones or $\mathrm{m}^{3}$. Source: own elaboration based on:: The balance of mineral resources deposits in Poland as of 31.12.2019 Polish Geological Institute-National Research Institute (PGI-NRI) 2020, Warsaw, www.teraz-srodowisko.pl/media/pdf/aktualnosci/8930-bilans-zloza-kopali-2019.pdf [access: 23.01.2021]

Tab. 1. Udokumentowane zasoby geologiczne bilansowe, przemysłowe stan na 31.12 .2019 rok w $\mathrm{mln}$ ton lub $\mathrm{m}^{3}$

\begin{tabular}{|c|c|c|c|c|c|c|c|}
\hline \multirow{2}{*}{$\begin{array}{l}\text { Type of mineral } \\
\text { deposit }\end{array}$} & \multicolumn{2}{|c|}{$\begin{array}{l}\text { Amount of } \\
\text { deposit }\end{array}$} & \multirow{2}{*}{ Extraction } & \multirow{2}{*}{$\begin{array}{l}\text { Total } \\
\text { amount of } \\
\text { deposit in } \mathrm{m} \\
\mathrm{t} / \mathrm{m} / \mathrm{m}^{3}\end{array}$} & \multicolumn{3}{|l|}{ Including: } \\
\hline & total & active & & & $\begin{array}{l}\text { Balance } \\
\text { deposit }\end{array}$ & $\begin{array}{l}\text { Off balance } \\
\text { deposit }\end{array}$ & $\begin{array}{l}\text { Industrial } \\
\text { deposit }\end{array}$ \\
\hline Natural gas & 305 & 201 & 5.0 & 219202.5 & 141971.4 & 2277.7 & 74953.4 \\
\hline Petroleum & 87 & 57 & 0.94 & 36.0 & 22.6 & 0.40 & 13.0 \\
\hline Lignite & 91 & 9 & 52.9 & 27773.8 & 23261.8 & 3517.5 & 994.5 \\
\hline Hard coal & 162 & 46 & 64.1 & 82462.8 & 64329.8 & 13353.8 & 4779.2 \\
\hline Zinc and lead ores & 21 & 3 & 1.5 & 151.9 & 92.2 & 55.9 & 3.8 \\
\hline Copper ore & 13 & 6 & 29.88 & 3909.8 & 1951.2 & 801.3 & 1157.3 \\
\hline Rock salt & 19 & 6 & 4.7 & 22017.72 & 90.32 & 20160.5 & 1766.9 \\
\hline $\begin{array}{l}\text { Gypsum and } \\
\text { anhydrite }\end{array}$ & 15 & 4 & 1.1 & 340.2 & 253.9 & 20.0 & 66.3 \\
\hline $\begin{array}{l}\text { Crushed stones } \\
\text { and block stones }\end{array}$ & 742 & 316 & 78.7 & 15645.7 & 11543.3 & 529.1 & 3573.3 \\
\hline $\begin{array}{l}\text { Limestones and } \\
\text { marls for cement } \\
\text { industry }\end{array}$ & 69 & 20 & 28.2 & 15668.7 & 12694.8 & 953.3 & 2020.6 \\
\hline Sand and gravel & 10504 & 3886 & 182.8 & 24321.3 & 19742.7 & 409.8 & 4168.8 \\
\hline Peats in total & 298 & 81 & 1189.0 & 134.59 & 92.42 & 6.54 & 35.63 \\
\hline
\end{tabular}

rationality, alignment, motivation and empowerment [Lozano R, 2008, pp. 499-509] shall be included in a long-term strategy which allow to achieve the aforementioned objective.

A cost-benefit analysis should not be drawn up for each of these elements separately but for all of them together in accordance with the principle of sustainable development.

Thus, the implementation of sustainable development is a process of continuous integration of activities in such key areas as:

- technical-economic area ensuring economic growth

- ecological area guaranteeing the raw materials and environment protection

- social area ensuring that the common social and environmental objective is achieved within the framework of Corporate Social Responsibility and Corporate Sustainability and Responsibility.

The statutory research conducted in 2019 and 2020 in Warsaw by The Collegium of Business Administration Warsaw School of Economics shows that $37.5 \%$ of survey respondents are aware of the base definition, of which the largest $(80 \%)$ percentage concerned production companies. In the service industries, the conscious balance of economic, social and ecological objectives indicates $14.3 \%$ of respondents. There was a negative answer in the administration section. It was found that:

- $50 \%$ of respondents understand the base definition in one or at most two aspects i.e. ecological or combination: ecological-economic aspect or ecological-social aspect etc.

- $\quad$ Seven (7) respondents which is $43.8 \%$ of surveyed people have taken specific actions in the field of sustainable development.

- One (1) company indicates sense of security as an important aspect of sustainable development

- Only $12.5 \%$ of the surveyed companies indicate the link between activities undertaken in the area of sustainable development and the size of the organiza- tion, the industry in which its operates, as well as the organizational culture of the company and the region of organization origin.

Based on comparative thinking with analyzing these results it can be assumed that companies from mining sector present a similar understanding of the principles of sustainable development. When analyzing an understanding of the notion sustainable development, it should be noted that in case of activities relating to the exploitation of mineral resources, this term acquires a very specific meaning. It is inherent in this activity that include non-renewable resources therefore the first and crucial principal of sustainable development must be rational and economical both the extraction and use of mineral resources (Dubiński, 2013, p.2).

\section{The rational exploitation and use of natural resources.} Preserving natural resources.

Mineral resources are the materials of intrinsic economic interest extracted from deposits. Mineral resources occurring in Poland are classified into following basic groups, i.e.

- Energy resources: hard coal, lignite, natural gas, peat;

- Chemical raw materials: rock salt, gypsum, sulphur;

- Metal ores: zinc and lead deposits, molybdenum-tungsten-copper ores, iron ore

- Natural stones: sandstone, limestone, marls, dolomites, sand, gravel, clays

- Healing water

Mineral resources extracted and used by humans have always been a condition for the economic growth and civilization development of societies and states which was clearly reflected during The World Mining Congress: Everything begins with mining which took place in USA in 2000. (...) Many areas, both in the past and in the modern times, used the development of mining to their own development [Dubiński , 2013, p.2]. In the publication The balance of mineral resources deposits in Poland prepared by Polish Geological 
Tab. 2. The economy of the Silesian Voivodeship in the context of mining activities in the period 2010-2018. Source: own elaboration based on Central Statistical Office (CSO) Silesian Voivodship (2018), www.katowice.stat.gov.pl/opracowania-biezace/opracowania-sygnalne [access 30.01.2021]

Tab. 2. Gospodarka województwa śląskiego w kontekście działalności wydobywczej w latach 2010-2018

\begin{tabular}{|c|c|c|c|c|c|c|c|c|}
\hline Years & 2010 & & 2015 & & 2017 & & 2018 & $\begin{array}{r}\text { Dynamics } \\
\text { in \% } \\
\text { 2018: } 2010\end{array}$ \\
\hline \multicolumn{9}{|c|}{ The sold industry output ( in millions of PLN) } \\
\hline $\begin{array}{l}\text { Total } \\
\text { including: }\end{array}$ & 173623.3 & 193638.7 & 111.5 & 221533.3 & 114.4 & 233039.2 & 105.2 & 134.2 \\
\hline $\begin{array}{l}\text { public } \\
\text { sector }\end{array}$ & 37833.0 & 27978.2 & 74.0 & 31404.1 & 112.2 & 33282.9 & 106.0 & 88.0 \\
\hline $\begin{array}{l}\text { private } \\
\text { sector }\end{array}$ & 135790.3 & 165660.5 & 122.0 & 190128.2 & 114.8 & 199756.3 & 105.1 & 147.1 \\
\hline \multicolumn{9}{|c|}{ The mining industry } \\
\hline $\begin{array}{l}\text { Total, } \\
\text { including: }\end{array}$ & 23162.7 & 21351.9 & 92.2 & 23368.5 & 109.4 & 24678.6 & 105.6 & 106.5 \\
\hline $\begin{array}{l}\text { coal and } \\
\text { lignite }\end{array}$ & 22462.1 & 19514.1 & 88.1 & 21393.0 & 109.6 & 22332.9 & 104.4 & $99, .4$ \\
\hline $\begin{array}{l}\text { other } \\
\text { mineral } \\
\text { resources }\end{array}$ & 700.6 & 1837.8 & 262.3 & 1975.5 & 107.5 & 2345.7 & 118.7 & 334.8 \\
\hline \multicolumn{9}{|c|}{$\begin{array}{l}\text { The percentage share of sold production of mineral resources in the total sold production in } \\
\text { Silesian region }\end{array}$} \\
\hline & 13.34 & 11.02 & $x$ & 10.54 & $x$ & 10.58 & $x$ & $x$ \\
\hline
\end{tabular}

Institute-National Research Institute (PGI-NRI) presented data on 14247 domestic mineral raw materials deposits documented in Poland as of 31.12.2019.

Table 1 provides the total mineral resources split for balance, off-balance and industrial, as well as total amount of deposit including active ones and finally average annual extraction of minerals.

Some discrepancies between the number of documented deposits (12 326) and the number of active deposits with exploitation (4 635) is only $37,6 \%$ and is caused by the fact that existing legislation about including mineral deposits in the local spatial development plan do not guarantee the security of access to deposits for exploitation purposes. Another substantial barrier in starting the exploitation is the ownership of mineral deposits (mostly in private lands) located in the near-surface zone with the ownership of the land property. The further limitation is that decisions on the arrangement of the area are made by municipalities and they are often based on particular interests of local lobby [Radwanek-Bąk, 2010, p.4].

\section{The key elements of sustainable development}

The public acceptance of modern mining which has negative impact on environment and causes less or more discomfort to people who live in mining areas and their neighborhood is crucial for its activity. The need for sustainable management of mineral resources applies to all stages of deposit management: to begin with documentation, through exploitation, material excavation, use of final raw material and then secondary raw material. In the light of presented mineral deposit base and the prospects for Polish mining industry it can be concluded that the only reasonable approach is to maintain sustainable mining and sustainable management of mineral resources. Despite the mentioned statistics about companies exploited mineral resources in Poland, the wellknown from its mining tradition is

Despite the statistics mentioned, the mining companies are operating mineral resources, Silesia is the most famous for its mining traditions. Silesia region covers an area of 12
290.4 square kilometers, which represents $3.9 \%$ of the country. It is inhabited by 4616 million people which is $12 \%$ of the country's population. This region is also characterized by the highest population density in the country which is 375 people/km2 . GDP per capita is PLN 39.7 thousand/ 1 inhabitant which represents $107 \%$ of the average national GDP. For these reasons, the Silesian Voivodeship is used in the article to illustrate the technical and economic conditions determining economic growth as a basis of sustainable development.

Economic growth for the business entities in mining sector means the long-term stability both in the planned production output as well as satisfying the requirements of customers and finally achieve the economic efficiency by selling the extracted resources. The data presented in Table 2 specifies the sold production of mining industry in the Silesian region: over the last decade there has been a systematic decreasing in the share of the sold production of mining industry in the general industry sales (from $13.34 \%$ in 2010 to $10.58 \%$ in 2018.)

3.The environmental challenges - the operational security of agglomerations on the area of exploitations or its neighborhood

The environmental challenges are the major problems for the mining of all types of deposits. The requirements relating to the protection of living environment and landscape are the potential sources of conflict. These challenges comply with the second pillar of sustainable development. In global mining, these challenges cover a wide range of problems and covers all elements of the environment, meaning the surface of the earth, water and air.

Practically every mining activity affects the natural environment to some extent [Dubiński, 2013, p. 4]. Above all, this activity causes the changes: ground deformations - depressions; horizontal deformations, discontinuous deformations etc., seismicity induced by mining activities, changes of water relationships, soil sterilization, dusts and gases emissions, noise and others. Under European Union law and Polish law 
Tab. 3. The total number of economic entities running mining activities of mineral resources in Poland. Source: own elaboration based on: National portal of mineral and raw materials http://surowce-kopalnie.pl/ [access: 11.02.2021] and GPW Main Market https://www.gpw.pl/spolki [access:

$$
\text { 11.02.2021] }
$$

Tab. 3. Liczba podmiotów gospodarczych ogółem prowadzących działalność wydobywczą surowców mineralnych w Polsce

\begin{tabular}{|l|c|c|}
\hline \multicolumn{1}{|c|}{ Total producers } & number & \% \\
\hline GPW Non-listed Companies & 321 & 96.7 \\
\hline GPW Listed Companies & 3.3 & 11 \\
\hline Total & 332 & 100.0 \\
\hline
\end{tabular}

there is a great emphasis on the necessity to conduct public consultations. This issue is regulated in the Constitution of the Republic of Poland as well as in the above-mentioned legal regulations.

Social problems related to the extraction of mineral resources often take the form of social conflicts which have twofold sources:

Companies do not take into account social and environmental aspects in their activities choosing the economic aspects as priority. Sometimes the value of social and environmental elements are incorrectly determined as a part of the balance of profits and losses for individual geological and mining projects.

Society rejects projects where, although social and environmental elements have been taken into account and correctly valued but it has been found that the net economic benefits are higher than the net losses to the society and the environment. The lack of social acceptance in this case may be due to the following reasons:

- The lack of information meaning no detailed information about planned and ongoing projects in the context of sustainable development.

- Lack of public awareness and education in the field of sustainable development. Furthermore, in extreme cases, providing the society with incorrect information, for example, creating an image of mining as industry based on outdated, environmentally aggressive technology in the media and schools. Lobbying ecological groups and economic potentates who often declare that they care for the environment and the public good but they really protect their own interests;

- $\quad$ NIMBY phenomenon (not in my backyard) refers to the propensity of local citizens to insist on siting unwanted but important and necessary facilities anywhere but nowhere near them.

The major problem remains the conflict of interests between companies and local authorities which striving to win as many voters as possible, often act opportunistically and shortsightedly.

To ease currency tensions and conflict situations the following actions should take place:

Initiating information campaign on sustainable development for local communities and municipal authorities; promoting knowledge about sustainable development as well as finding methods of popularizing knowledge about the importance of raw materials for the development of the economy, including introducing the issue of raw materials to the curricula of schools and universities.
- A legal warranty that the municipality will allocate part of the mining fee to the investment e.g. the construction of infrastructure and job creation which might compensate local communities for negative impact of mining activity to environment.

Promoting Corporate Social Responsibility in strategies of companies - not only economic ones but also social and environmental aspects. Bearing in mind that application of Corporate Social Responsibility is optional, the benefits of its use should be communicate to the companies e.g. a positive image for the company and therefore increasing its value.

Promoting the benefits of dialogue with local communities using reliable information

Promoting good practices concerning the sustainable development. The European Commission has recognized as good practice the process of opening the mine Wolfram Bergbau und Hütten AG in Austria. The mine is located in a nature reserve near the national park and its construction required the reconciliation of tourist and natural assets with the extraction of raw materials. The cooperation between pro-ecological groups, local community, investors, the nextdoor neighbors and other stakeholders was the key to the success. The another example of good practice is initiative Towards Sustainable Mining (TSM) prepared by the Mining Association of Canada (MAC) and recently also adopted in Finland. The main three TSM guiding principles are: engaging and supporting dialogue with community, protecting the health and safety of the employees, contractors and communities and practicing continuous improvement in all facets of mining operations.

Another example is the activities of Swedish LKAB company which declared to purchase all properties in old Kiruna city and relocated it three kilometers to the East. Kiruna is located on valuable iron ore which exploitation is threatening the city that is why LKAB has taken steps to take into account the needs of residents and reindeer breeders. The whole process of moving the city will take at least 20 or 30 years. It will cost approximately one billion dollars [Nowacka- Isaksson, 2015].

The Silesian - Opole region is associated with mining in Poles awareness. The history of local exploitation and mining traditions of this region cast many centuries back. During the Neolithic Age the flint was mined with earthworks in the neighborhood of Raciborz. During the first centuries A.D. the iron ore was exploited in the same region [Molenda, 2005, pp.187-196]. Currently in Poland there are 332 economic entities operating in the mineral resources sector and 3.3\% (11) of them are listed on the capital market of the Warsaw Stock Exchange. 
Tab. 4 . Employment and workplace accidents in the Silesia region in 2010-2018. Source: own elaboration based on CSO Silesian Voivodship (2018) www.katowice.stat.gov.pl/opracowania-biezace/opracowania-sygnalne [access 30.01.2021]

Tab. 4. Sytuacja zatrudnieniowa i wypadkowa w regionie śląskim w latach 2010-2018

\begin{tabular}{|c|c|c|c|c|c|c|c|c|}
\hline Years & 2010 & 2015 & & 2017 & & 2018 & & $\begin{array}{c}\text { Dynamics } \\
\text { in } \% \\
2018: \\
2010\end{array}$ \\
\hline \multicolumn{9}{|c|}{ The average employment in the industry (the number of employees) } \\
\hline $\begin{array}{l}\text { Total } \\
\text { including: }\end{array}$ & 440604 & 425324 & 96.5 & 435208 & 102.3 & 442013 & 101.6 & 100.3 \\
\hline $\begin{array}{l}\text { in coal and other } \\
\text { raw materials } \\
\text { mining }\end{array}$ & 119006 & 98402 & 82.7 & 84662 & 86.0 & 85316 & 100.8 & 77.6 \\
\hline \multicolumn{9}{|c|}{$\%$ share of people employed in the mining industry in total employment in industry } \\
\hline & 27.0 & 23,1 & $\mathrm{x}$ & 19.4 & $\mathrm{x}$ & 19.3 & $x$ & $x$ \\
\hline \multicolumn{9}{|c|}{ Working conditions- safety - injured } \\
\hline $\begin{array}{l}\text { Total, } \\
\text { including: }\end{array}$ & 13802 & 12156 & 88.1 & 12265 & 100.9 & 12026 & 98.1 & 87.1 \\
\hline $\begin{array}{l}\text { In industry overall } \\
\text { including: }\end{array}$ & $x$ & $\mathrm{x}$ & $x$ & $x$ & $x$ & $\begin{array}{r}5903 \\
(49.8 \%) \\
\end{array}$ & $x$ & $\mathrm{x}$ \\
\hline $\begin{array}{l}\text { Mining and } \\
\text { extraction }\end{array}$ & $x$ & $x$ & $x$ & $x$ & $\mathrm{x}$ & $\begin{array}{r}1524 \\
(25.8 \%)\end{array}$ & $x$ & $\mathrm{x}$ \\
\hline \multicolumn{9}{|c|}{$\%$ share of people injured in accidents at work in employment in individual years } \\
\hline In industry overall & 3.13 & 2.85 & $x$ & 2.81 & $x$ & 2,72 & $x$ & $\mathrm{x}$ \\
\hline In mining & 11.59 & 12.35 & $x$ & 14.48 & $x$ & 14.09 & $x$ & $\mathrm{x}$ \\
\hline
\end{tabular}

On the basis of detailed author's own research carried out on the basis of existing data concerning the entities listed in Table 2 it can be noticed that only $11.7 \%$ (39) entities from mineral resources sector fully apply the sustainable development principles and they are all listed companies and 28 from unlisted companies. These entities disclose information about implemented sustainable development principles which can be found in the updated reports and information to customers.

In the group of non-listed entities only 50 partially apply the principles of sustainable development which are limited to the use of the integrated management system. This should be strongly underlined because the responsible and effective management, as well as ISO14001 that specifies requirements for an effective environmental management system in organizations, are crucial for sustainable development, economic progress and increased security of raw materials, both nationally and throughout Europe. These entities account for 15.1\% (150) of the entire surveyed population.

With regard to the remaining 243 companies only economic performance was found. No pro-ecological and pro-social performance were found indicating any sustainable development awareness which is equivalent to lack of information on this subject.

\section{Legal conditions for the management of deposits and mineral resources}

National Development Strategy 2020 which emphasizes the main goals for country development in medium term as well as Innovation and Efficiency of the Economy Strategy (SIEG) and Strategy for Energy Security and Environment which are two from nine integrated strategies which serve to implement objectives included in medium term strategy. These documents are the only ones that provide the subject of deposits and so far they have determined a differentiated approach to the management of non-energy raw materials and Energy raw materials in Poland. The same distinction between Energy and non-energy raw materials was made in European Union policy. Until the finalization of The Energy Policy of Poland up to 2050 the Action Plan for the non-energy raw materials supply security shall be applied.

In Poland the institutional competences in the area of non-energy and non-renewable resources are not centralized. The specific aspects of the policy in this area can be assigned to the following organs of state administration (according to The Act of 4th September 1997 on Branches of Government administration, amended 19th November 2015), management of mineral deposits (the Ministry of State Assets), economy (the Ministry of Economic Development, Labour and Technology), regional development (the Ministry of Economic Development, Labour and Technology), foreign affairs (the Ministry of Foreign Affairs), construction, planning, area management and housing (the Ministry of Infrastructure), science and higher education (the Ministry of Science and Higher Education),public finance (the Ministry of Finance), treasury (Ministry of the Treasury - since od 15th November 2019 as the Ministry of State Assets), labour (the Ministry of Economic Development, Labour and Technology). Moreover, the geological administration authorities are playing an important role (Chief National Geologist, Marshals of the Voivodships, District Governors), the State Geological Service, the mining supervisory authorities, the Patent Office, the Maritime Offices and institutions controlled by the Prime Minister e.g. CSO, PPO and others.

The legal instruments of the policy in the field of non-energy non-renewable resources in Poland are provided in several legal acts, including, in particular:

- Act of 9 June 2011 Geological and Mining Law (Journal of Laws - Dz. U. 2016, item 1131) 
Tab. 5. Number of entities conducting research activity and the expenditures on research and development activity in the mining industry in 20102018. Source: own elaboration based on CSO Silesian Voivodship www.katowice.stat.gov.pl/opracowania-biezace/opracowania-sygnalne [access 30.01.2021] and CSO Research and development activities in 2018 https://stst.gov.pl/obszary-tematyczne/nauka-i-technika-spoleczenstwo-informacyjne/nauka-i-technika/dzialalnosc-badawcza-i-rozwojowa-w-polsce [access 30.01.2021]

Tab. 5. Liczba podmiotów prowadzących działalność badawczą oraz nakłady na działalność badawczą i rozwojową ponoszone w przemyśle wydobywczym w latach 2010-2018

\begin{tabular}{|c|c|c|c|c|c|c|c|c|}
\hline Years & 2010 & \multicolumn{2}{|l|}{2015} & 2017 & & \multicolumn{2}{|c|}{2018} & $\begin{array}{l}\text { Dynamics } \\
\quad \text { in } \% \\
2018: \\
2010\end{array}$ \\
\hline \multicolumn{9}{|c|}{ Entities conducting R\&D activity in the country } \\
\hline Country in total & 3474 & & 4427 & & 5102 & & 5779 & $\mathbf{x}$ \\
\hline \multicolumn{9}{|c|}{ Entities conducting research activity (number) in the Silesia region } \\
\hline Silesia in total & 234 & 493 & 210.7 & 627 & 127.2 & 622 & 99.2 & 265.8 \\
\hline $\begin{array}{l}\% \text { share to the } \\
\text { country }\end{array}$ & $6.7 \%$ & $x$ & $\mathrm{x}$ & $x$ & $\mathrm{x}$ & $10.8 \%$ & $x$ & $\mathrm{x}$ \\
\hline \multicolumn{9}{|c|}{ Expenditure on research and development in PLN thousand } \\
\hline Country in total & $\begin{array}{r}16 \\
68000 \\
\end{array}$ & 18061000 & 111.7 & 20578000 & 113.9 & 25648000 & 124.6 & 158.6 \\
\hline Silesia in total & 848800 & 1352200 & 159.3 & 1530500 & 113.2 & 1871200 & 122.3 & 220.45 \\
\hline $\begin{array}{l}\% \text { share to the } \\
\text { country }\end{array}$ & $5.2 \%$ & $7.5 \%$ & $\mathrm{x}$ & 7.4 & $\mathrm{x}$ & $7.3 \%$ & $x$ & $\mathrm{x}$ \\
\hline \multicolumn{9}{|c|}{ Expendatiture on innovation activity in PLN thousand } \\
\hline $\begin{array}{l}\text { Total } \\
\text { including: }\end{array}$ & $\begin{array}{r}3871 \\
815 \\
\end{array}$ & 3359642 & 86.8 & 3027921 & 90.1 & 3118850 & 109.6 & 85.7 \\
\hline $\begin{array}{l}\text { Mining and } \\
\text { extraction }\end{array}$ & $x$ & $\mathrm{x}$ & $x$ & $\mathrm{x}$ & $x$ & $\begin{array}{r}213221 \\
(6.8 \%) \\
\end{array}$ & $x$ & $x$ \\
\hline
\end{tabular}

- $\quad$ Act of 27 April 2001 Environmental Law (Journal of Laws - Dz. U. 2016, item 672)

- Act of 10 April 1997 The Energy Law (Journal of Laws - Dz. U. 2020, item 833, consolidation)

- $\quad$ Act of 27 March 2003 The Law on Land Development (Journal of Laws - Dz. U.2016, item 778

- Act of 2 July 2004 on Freedom of Economic Activity, (Journal of Laws - Dz. U.2016, item 1829)

- Act of 20 February 2015 The Renewable Energy Sources Act (Journal of Laws - Dz. U.2021, item 234, consolidation)

- Act of 3 October 2008 on the Disclosure of Information about the Environment and its Protection, Public Participation in Environmental Protection and Environmental Impact Assessments (Journal of Laws - Dz. U.2016, item 353)

- The Civil Code

A major challenge for the development of coherent raw material policy is the great number of institutions and legal acts as well. And that is not only a problem of Poland, generally, it can be observed in economies all over the world. Since 2015 in Poland have been carried out the works on a document National Raw Materials Policy which contribute to the establishment of the Committee for Sustainable Mineral Resources Management of the Polish Academy of Sciences in April 2018. Till then Poland did not have raw material policy, any vital tools to its performance, legitimate geological service with specific tasks and acting exclusively on behalf of the state and in the interests of the state and society [Hausner (edit.), 2015, p.118].
The preparation of legal acts and documents is an essential core of eco-development in Poland at the government level. These acts shall set the broad lines of activities for sustainable development. According to Smakowski T., Szamałka K, [2016, p. 276] any new legal solutions must take into account mostly EU arrangements in the area of the economy of raw materials which include sustainable development and environmental conditions.

\section{Work safety}

The mining industry in 21 st century, even maintaining the direction of sustainable development, has to guarantee its employees safe working conditions. The issue of work safety due to its complexity is the major challenge for mining science and practice. The constantly increasing depth of exploitation, which is now a global trend, makes work safety a crucial aspect of sustainable development of mining industry.

The technologies used in the exploitation of deposits and the acquisition of mineral resources have to minimize or eliminate the negative effects of mining and extraction processes. Furthermore, a key issue is the development of new technologies of recultivation the exploited areas. The diverse technologies of recultivation of post-mining areas are developed and implemented both in global and Polish mining, and they bring beneficial effects. It should be also stressed that special care for the environment is one of the most important aspects in social responsibility and the achievement of a common social and environmental objective, Since the public awareness that mineral deposits are a non-renewable good is unfortunately poor, its improvement or change of the situa- 
tion in this area is another challenge that should be followed by specific actions [Dubiński, 2013, p. 5].

The scale of the issue, e.g. the size of employment in industry in the last decade in Silesia region, as well as the number of people injured in accidents related to work in mining industry is presented in table no.4. Both the total employment in 20102018 and the number of employees in the mining industry remained unchanged. But the share of employees in the mining industry in total employment in industry decreased significantly from $27 \%$ in 2010 to $19.3 \%$ in 2018 which is undoubtedly the result of organizational and technological changes in the processes of extracting raw materials and sustainable development regime linked to this sector. What is particularly worrying is that the share of people injured in accidents at work in the mining industry has increased from $11.59 \%$ in 2010 to $14.09 \%$ in 2018 with a reduced accident rate in the total industry.

This situation create a lot of space to institutions which are conducting research and development activities not only in order to gain new knowledge but above all to obtains specific and useful solutions which will minimize the negative effects of human activity in order to protect human life and health. The profitable geological and mining investments as well as research and development prove the success of the properly conducted public policy of raw materials. Table 5 gives an overview on this subject in mining industry. The number of entities conducting research activity in Silesia over the period under study increased more than two and a half times, showing the dynamics of $265.8 \%$, and their share in the total number of entities in R\&D in 2018 in the country amounted to $10.8 \%$ compared to the share of at the beginning of the decade at $6.7 \%$. Expenditure on research and development activities in Silesia also shows significant dynamics compared to 2010: increased as much as $120.5 \%$, while gross expenditure on R\&D in the country increased by $58.6 \%$ during this period. Over the decade the share of expenditure on R\&D activities in the institutions operating in Silesia in relation to the national ones has increased from $5.2 \%$ to $7.3 \%$. Although these figures are insufficient however the upgrade trend that has been observed over the last decade looks promising. Presumably, maintaining the dynamics of positive changes will increase the pace of sustainable development of the mining activity.

\section{Conclusion}

The scale of problems related to the management of mineral resources, affecting modern societies, including our country, is disproportionately greater than the scale of activities, programs and projects undertaken in order to solve them. It results from the fact that these activities are limited to the pilot projects which are undertaken only for image enhancement and gaining CSR goals rather than serving to local communities. The research results confirm the main hypothesis of the article that not all companies apply the principles of the sustainable development as it is defined. Some companies apply these rules, but not the full extent of them. The sub-hypotheses presented in the introduction have been confirmed as well. There is untapped potential in Polish mineral resources sector in particular with raising awareness of sustainable development among companies, also the legal conditions are insufficient in this matter.

In addition, the above conclusion is confirmed by the results of the previously cited studies, which show that:

Companies, to a great extent, confuse CSR principles with sustainable development. Great number of them refer only to the ecological dimension.

Organizations undertake sustainability actions between financial, environmental and social performance but these actions are coincidental rather than being a part of planned strategy of sustainable development.

Most of the surveyed organizations are not consciously managed in a sustainable manner (balancing social, economic and social goals) $-63 \%$.

More than half of the surveyed organizations implement some specific actions for sustainability in the financial, environmental or social area however they do not necessarily connect these 3 aspects $-56 \%$.

The low awareness of entrepreneurs dealing with the mineral resources industry who do not apply the principles of sustainable development, as shown in the research, does not bode well for a quick elimination of socio-economic problems affecting Polish society. In the context of the message from the United Nations Manifesto titled: "Global Economic Ethic Consequences for Global Businesses" launched on October 6 2009, it is important to shift the pivotal role from the current CSR as Corporate Social Responsibility to CSR as Sustainable and Responsible Business. This change means that the most important factors are "sustainable development" (stemming from the ecological movement), which is the goal that is being pursued through the implementation of challenges, vision and strategy, and "social responsibility". To make the set goals achievable appropriate actions must be taken as well as the proper management of economic and social processes. Therefore, it is a misunderstanding to claim that the purpose of business is to make a profit to its stakeholders. This is only a means to achieve the ultimate goal of acting to benefit society. The final effect of these activities is the provision of safe, high-quality products and services which will contribute in ensuring future generations at least today's living conditions without worsening the existing ecological and social systems. But it will be possible if the sustainable development regime in its three pillars. 


\section{Literatura - References}

1. Badania statutowe SGH Kolegium Nauk o Przedsiębiorstwie (2019-2021); Zadanie badawcze: Zarządzanie kapitałem ludzkim w warunkach zrównoważonego rozwoju (etap III ).

2. Dubiński J. (2013), Zrównoważony rozwój górnictwa surowców mineralnych, Katowice: GIG Journal of Sustainable Mining vol. 12 ( 2013), No 1, p.1.

3. Gałuszka A., Migaszewski Z., (2009), Problemy zrównoważonego użytkowania surowców mineralnych, Kielce: UJK Instytut Chemii „Problemy Ekorozwoju”, vol 4, No 1, s. 123-130.

4. Główny Rynek GPW https://www.gpw.pl/spolki [dostęp: 11.02.2021].

5. GUS województwo śląskie (2018), www.katowice.stat.gov.pl/opracowania-biezace/opracowania-sygnalne [access 30.01.2021]

6. GUS działalność badawczo i rozwojowa w Polsce w $2018 \mathrm{r}$. https://stst.gov.pl/obszary-tematyczne/nauka-i-technika-spoleczenstwo-informacyjne/nauka-i-technika/dzialalnosc-badawcza-i-rozwojowa-w-polsce [access 30.01.2021].

7. Hausner J. (red.) (2015) Polityka surowcowa Polski. Rzecz o tym czego nie ma, a jest bardzo potrzebne. Kraków: Fundacja Gospodarki i Administracji Publicznej.

8. Lozano R., (2008) Developing collaborative and sustainable organizations, Journal of Cleanear Production, No. 16, pp. 499-509.

9. Ministerstwo Rozwoju (2017) Surowce dla Przemysłu- Plan działań na rzecz zabezpieczenia podaży surowców nieenergetycznych Warszawa, 15/02/2017; www.orka2.sejm.gov.pl/INT8.ns/klucz/ATTB6HI\$FILE/i26415-o1_1.pdf [dostęp:29.01.2021].

10. Molenda T.,(2005), Górnice środowiska antropogeniczne- obiekty obserwacji procesów geomorfologiczno-biologicznych ( na przykładzie województwa śląskiego, Wrocław: Prace Naukowe Instytutu Górnictwa Politechniki Wrocławskiej, nr 111, 187-196.

11. Nadolna B., (2009), Metodologiczne aspekty prac naukowych z zakresu nauk ekonomicznych, Szczecin: Zachodniopomorski Uniwersytet Techniczny, Oeconomica 273 (56), 135-148

12. Nieć. M., (1999), Złoża antropogeniczne, W: „Przegląd Geologiczny” vol. 47, no 1. s. 93-98.

13. Nowacka -Isaksson Anna (2015) Szwecja- wielka przeprowadzka https://www.rp.pl/artukul/1191544-Szwecja-Wielka-przeprowadzka.html

14. Ogólnopolski portal kopalin i surowców http://surowce-kopalnie.pl/ [access: 11.02.2021].

15. Państwowy Instytut Geologiczny- Państwowy Instytut Badawczy (2020). Bilans zasobów złóż kopalin w Polsce wg stanu na 31 XII 2019 r. Warszawa www.teraz-srodowisko.pl/media/pdf/aktualnosci/8930-bilans-zloza-kopali-2019. pdf [access 23.01.2021].

16. Radwanek-Bąk B. (2010) Rozwój górnictwa zrównoważonego w Polsce https://www.kieruneksurowce.pl/artukul,3027,rozwoj-gornictwa-zrownowazonego-w-polsce.html [access: 26.01.2021]

17. Smakowski T., Szamałek K., (2016), Prawno-ekonomiczne uwarunkowania gospodarki złożami i surowcami mineralnymi, Kraków: Zeszyty Naukowe Instytutu Gospodarki Surowcami Mineralnymi i Energią Polskiej Akademii Nauk nr 96, p. 265-278.

18. Strategia w sprawie efektywnego wykorzystywania zasobów naturalnych obowiązująca w Unii Europejskiej [http:// europa.eu.int/com/environment/natres/index.htm.] [access: 28.01.2021].

19. Strzałkowski P., (2005) Zarys rozwoju technologii górnictwa podziemnego, Gliwice: Wydawnictwo Politechniki Śląskiej. 


\section{Aspekty zrównoważonego rozwoju w gospodarce surowcami mineralnymi}

Surowce mineralne zapewniaja wysoki standard życia współczesnych społeczeństw, gwarantując zaspokojenie zapotrzebowania na energię, materiały budowlane, a także stanowia podstawę przemystu i rozwoju technologicznego. Przed wspótczesnymi społeczeństwami stoi wyzwanie odwrócenia trendu sczerpywania się nieodnawialnych surowców mineralnych, a zrównoważony rozwój ma zapewnić możliwość przetrwania cywilizacji ludzkiej w obliczu zmniejszajacych się zasobów surowców nieodnawialnych (zwłaszcza energetycznych) oraz wzrastającej antropopresji i związanego z niq̨ zanieczyszczenia środowiska przyrodniczego. Ilość mineralnych surowców nieodnawialnych $w$ skorupie ziemskiej jest ograniczona, a ich regeneracja możliwa jedynie w specyficznych warunkach w czasie obejmującym kilka jeśli nie kilkanaście pokoleń (Gałuszka, Migaszewski, 2009, s. 123). W artykule stawiane sa pytania o to, w jaki sposób społeczeństwa moga zapobiec kryzysowi surowcowemu w przyszłości i czy to zadanie jest możliwe do wykonania. Mając to zadanie na uwadze należy do koncepcji gospodarki surowcami mineralnymi odnieść się w sposób zgodny z zasadami zrównoważonego rozwoju który ma zapewnić możliwość przetrwania cywilizacji ludzkiej w obliczu zmniejszających się zasobów surowców nieodnawialnych (zwłaszcza energetycznych) oraz wzrastającej antropopresji i związanego z nia zanieczyszczenia środowiska przyrodniczego

W artykule wskazano główne aspekty zrównoważonego rozwoju sektora wydobywczego w Polsce i wyzwania zwiazane zochrona środowiska naturalnego w kontekście nowego CSR, w którym chodzi o stworzenie i wdrożenie zrównoważonego i odpowiedzialnego modelu biznesowego, który przez zreformowany system finansowy i ekonomiczny sprawi, że tworzenie lepszej przyszłości będzie łatwiejsze, bardziej naturalne i opłacalne. Przedstawiono takie kluczowe elementy zrównoważonego rozwoju jak uwarunkowania gospodarcze i społeczne, wyzwania związane z ochrona środowiska, bezpieczeństwo funkcjonowania aglomeracji na terenach eksploatacji złóż lub w ich sąsiedztwie. Zwrócono uwagę na prawne uwarunkowania gospodarki złożami $i$ wydobytymi surowcami mineralnymi oraz bezpieczeństwo pracy i podejmowane działania w zakresie działalności badawczo-rozwojowej w sektorze.

Słowa kluczowe: surowce mineralne, zrównoważony rozwój, nakłady na działalność badawczo-rozwojowa 